Portland State University

PDXScholar

TREC Final Reports

Transportation Research and Education Center

(TREC)

$5-2008$

\title{
Linking Experiential Learning to Community Transportation Planning
}

Robert Parker

University of Oregon

Bethany Johnson

University of Oregon

Follow this and additional works at: https://pdxscholar.library.pdx.edu/trec_reports

Part of the Transportation Commons, Urban Studies Commons, and the Urban Studies and Planning Commons

Let us know how access to this document benefits you.

\section{Recommended Citation}

Parker, Robert and Bethany Johnson. Linking Experiential Learning to Community Transportation Planning. OTREC-ED-08-01. Portland, OR: Transportation Research and Education Center (TREC), 2008. https://doi.org/10.15760/trec.90

This Report is brought to you for free and open access. It has been accepted for inclusion in TREC Final Reports by an authorized administrator of PDXScholar. Please contact us if we can make this document more accessible: pdxscholar@pdx.edu. 


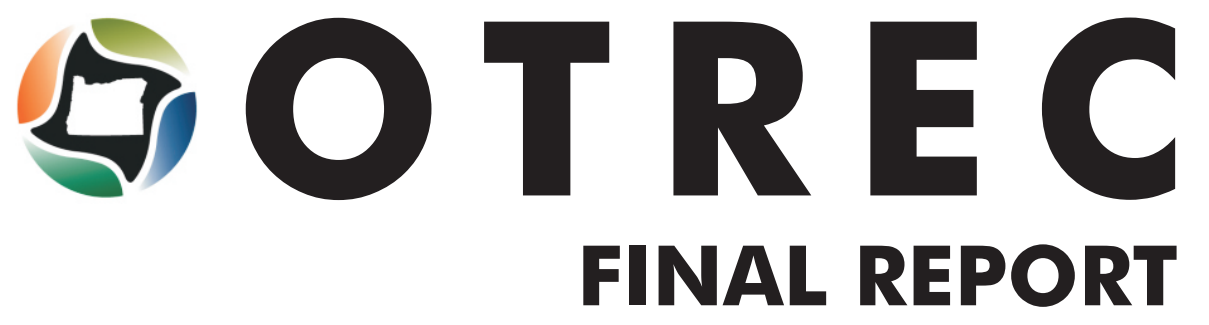

\section{Linking Experiential Learning to Community Transportation Planning}

OTREC-ED-08-01 May 2008 


\section{LINKING EXPERIENTIAL LEARNING TO COMMUNITY TRANSPORTATION PLANNING}

Final Report

OTREC-ED-08-01

by

Robert Parker, AICP

Bethany Johnson, AICP

University of Oregon

for

Oregon Transportation Research

and Education Consortium (OTREC)

P.O. Box 751

Portland, OR 97207

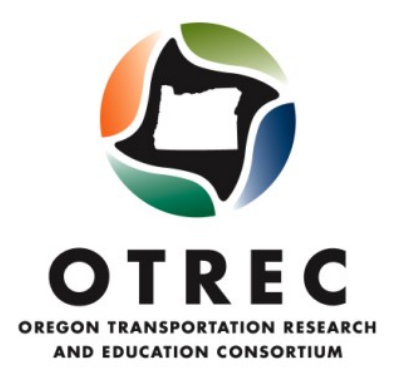

May 2008 



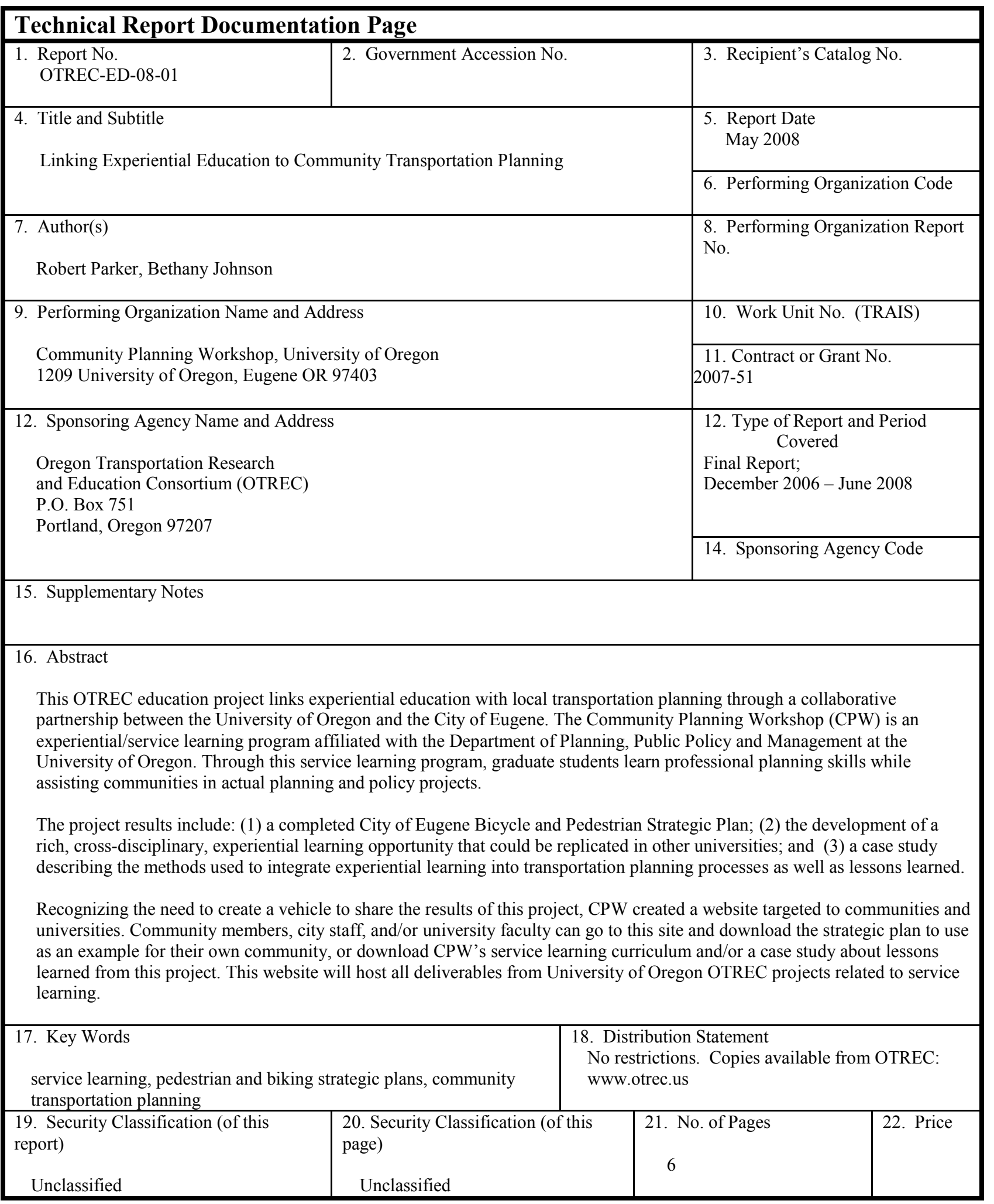




\section{ACKNOWLEDGEMENTS}

The Community Planning Workshop (CPW) would like to thank the Oregon Transportation Research and Education Consortium for funding this project, and all the students who eagerly learned about transportation planning and worked hard to create the project deliverables. Finally, CPW would like to thank the City of Eugene Transportation Planning Team for embracing the service learning model and working collaboratively with the Community Planning Workshop students. This project is an outstanding example of leveraging federal money, local dollars and university resources to create a true community-based project that can serve as a model for other communities and universities.

\section{DISCLAIMER}

The contents of this report reflect the views of the authors, who are solely responsible for the facts and the accuracy of the material and information presented herein. This document is disseminated under the sponsorship of the U.S. Department of Transportation University Transportation Centers Program in the interest of information exchange. The U.S. Government assumes no liability for the contents or use thereof. The contents do not necessarily reflect the official views of the U.S. Government. This report does not constitute a standard, specification, or regulation. 


\section{LINKING EXPERIENTIAL EDUCATION TO COMMUNITY TRANSPORTATION PLANNING}

\section{TABLE OF CONTENTS}

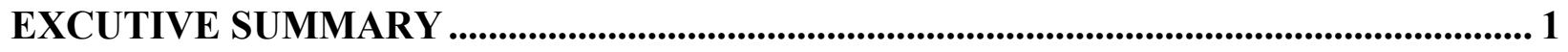

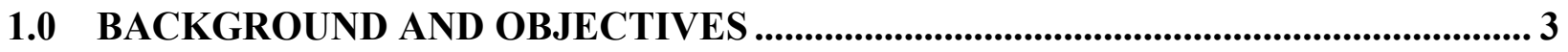

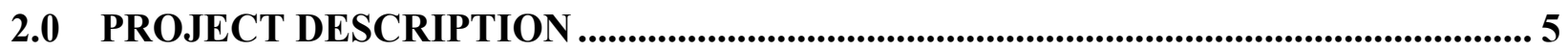

3.0 OUTCOME AND RESULTS ...................................................................................... 7

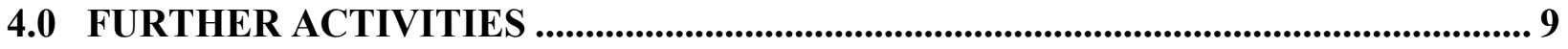

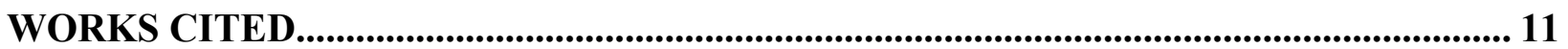




\section{EXCUTIVE SUMMARY}

This OTREC education project links experiential education with local transportation planning through a collaborative partnership between the University of Oregon and the City of Eugene. The Community Planning Workshop (CPW) is an experiential learning program affiliated with the Department of Planning, Public Policy and Management at the University of Oregon.

Through this service learning program, graduate students learn professional planning skills while assisting communities in actual planning and policy projects.

The project results include: (1) a completed City of Eugene Bicycle and Pedestrian Strategic Plan; (2) the development of a rich, cross-disciplinary, experiential learning opportunity that could be replicated in other universities; and (3) a case study describing the methods used to integrate experiential learning into transportation planning processes as well as lessons learned.

Recognizing the need to create a vehicle to catalogue and disseminate the results of this project, CPW created a website targeted to communities and universities. Community members, city staff, and/or university faculty can go to this site and download the plan to use as an example for their own community, or download information about CPW's service learning curriculum and/or a case study about lessons learned from this project. The website can be accessed at: (www.cscotrec.uoregon.edu).

This project involved a variety of people: approximately 500 community members provided input in the development of the strategic plan, 15 university graduate students conducted background research, facilitated meetings, and wrote the plan, 15 community members participated in the year-long Department Advisory Committee to develop the plan, 25 transportation professionals presented at the Biking and Walking Summits, and CPW estimates more than 100 participants will attend the three conference presentations. (Approximately 30 people attended CPW's presentation at the Oregon Public Works Association Conference in April; the two other presentations are scheduled for September 2008.)

Each of the project deliverables furthers stated OTREC and DOT priorities and goals for education projects, and will build support for innovative methods of teaching in the field of transportation study. 


\subsection{BACKGROUND AND OBJECTIVES}

Community planning researchers across the United States are identifying "automobile dependence as one of the greatest challenges facing cities at the beginning of the 21 st century" (as cited in Balsas, Cervero, 1997; Kay, 1997; Newman \& Kenworthy, 1999; Pucher, 2000; Balsas, 2001) due to its contribution to traffic congestion, construction and maintenance costs, urban sprawl, and environmental degradation. ${ }^{1}$ Transportation and urban design are also public health concerns; increased automobile use and decreased opportunities to walk and bike have been linked to obesity, asthma, and health problems associated with a sedentary lifestyle. ${ }^{2}$ Increasing non-motorized transportation, primarily bicycling and walking, has been demonstrated to be an effective means of reducing the negative consequences of automobile reliance while enhancing the livability of communities.

The City of Eugene has a history of thinking and acting boldly around walking and biking issues, and it wants to continue that legacy. The city has miles of off-street walking and biking paths and more bridges across the Willamette River for pedestrians and cyclists than for cars. Although it does have an extensive biking and walking infrastructure and numerous community biking and walking organizations, Eugene did not have a strategic plan dedicated to getting more people out walking and biking. In 2007, the City realized that it needed to develop a 5-year Strategic Plan outlining how to become a more walkable and bikeable city.

The City of Eugene contracted with Community Planning Workshop (CPW), a service and experiential learning program at the University of Oregon, to help develop the strategic plan. In addition to the long-term benefits for the Eugene community, developing the strategic bicycle and pedestrian plan provided graduate students a multi-disciplinary experiential learning opportunity that helped develop the skills needed for a career in transportation planning.

Educators have long worked to find pedagogical approaches that yield the best educational results. This is particularly true in the planning disciplines where there is an ongoing dialog among academics and practitioners about how to most effectively train aspiring professionals. ${ }^{3}$ To provide a mix of academic and practical experience, most academic planning programs include a mixture of theoretical and applied curriculum. The American Planning Association (APA) recognizes this need and as a result, APA accredited planning programs must have a "practicum" as a key program element. The Community Planning Workshop at the University of Oregon provides the "practicum" element for its students through its experiential model.

Experiential learning encourages the development of transferable skills (e.g. communicating, problem solving, presenting, working with others), more reflective practitioners, and results in a richer, more rewarding educational experience for students. ${ }^{4}$ Through facilitating public workshops, collaborating with planning professionals, group work, public presentations, and applied research, students go beyond academic coursework to build the skills demanded by the planning profession. Planning is a practice which is learned by practicing. Service learning provides the opportunity to practice. ${ }^{5}$ 
Not only did this project provide an educational opportunity for graduate students, but it also provided education for members of the Department Advisory Committee. According to one member:

"This was really my first time working on this type of project. I would like to say that I really appreciated how professional the students were, how well organized they were and I really appreciated the quantity and quality of work they did on the bike/ped strategic plan. I really amazed and inspired me to want to do more." 


\subsection{PROJECT DESCRIPTION}

Service learning lies at the heart of this project and forms the core of the methodology and project approach. Service-learning is a form of experiential education in which students engage in activities that address human and community needs together with structured opportunities intentionally designed to promote student learning and development.

\section{City of Eugene Pedestrian and Bicycle Strategic Plan}

This project created the City of Eugene's first Pedestrian and Bicycle Strategic Plan. This plan serves as a guide for how City departments, other agencies, community organizations, and individuals will work together to make Eugene a more walkable and bikeable city. To make this vision a reality, the plan identifies goals, strategies and actions that are tangible and achievable within the next five years. Actions address not only the pedestrian and bicycle infrastructure but other elements that impact walking and biking - such as safety, education, encouragement and funding.

The Community Planning Workshop (CPW) at the University of Oregon provided much of the support for the planning process especially in terms of public engagement and plan writing. Students worked closely with professionals in the transportation field, conducted background research, facilitated public workshops, and facilitated a Department Advisory Committee. In short, this project provided students direct, hands on experience in developing a Pedestrian and Strategic Plan for the City of Eugene - as well as the research methods and public process used to develop such plans.

The City created a project website that archives project documents including workshop reports, Summit reports, and the Strategic Plan: www.eugene-or.gov/walkbike

\section{The development of a rich, cross-disciplinary, experiential learning opportunity} This grant provided staff time and resources to enhance the Community Planning Workshop class. This class provides students from a variety of disciplines including city and regional planning, public policy, landscape architecture and environmental studies the opportunity to work together with city staff and community members in a structured and creative environment.

The CPW class meets three times a week for a total of 4.5 hours. Through structured class sessions led by students and faculty CPW addresses a broad range of planning topics and skills such as meeting facilitation, public presentations, and data analysis. CPW has posted the syllabi, class session outlines, assignments, and evaluation tools on the project website so that other faculty can gather ideas for their own service learning classes and projects.

\section{Case Study: Linking Experiential Education and Community Transportation Planning} This case study tells the story of a model Community-University Partnership between the University of Oregon and the City of Eugene that produced the Pedestrian and Bicycle Strategic Plan. Equally as important as the plan, the story provides the perspectives of graduate students, 
the university faculty, City of Eugene staff and community participants in the planning process. It touches on the complexities of transportation planning and how experiential education opportunities are successful ways to educate burgeoning planners. And lastly, the case study discusses what it takes to create successful partnerships between universities and practitioners in the field.

\section{Linking Experiential Education and Community Transportation Website}

By making the project outcomes available digitally, CPW hopes to facilitate other communities' and universities' use of experiential learning in transportation planning. As more service learning and transportation planning work is done at the University of Oregon, CPW will add to the website so that it will become a repository of information for communities and universities. 


\subsection{OUTCOME AND RESULTS}

"Perhaps the biggest benefit of the community-university partnership is the ability to tap into an energetic, skilled labor pool who is highly motivated to make this work. Students bring enthusiasm and commitment that is hard for a City staffer who has already done 100 similar projects to match. I was constantly pleased to see how well the students had worked with our ideas between meetings, shaping them into a more coherent whole without sacrificing the meaning people intended. I think it's also easier for University students to be open to ideas, whereas experienced City staff often have their views shaped by what has worked or not worked in the past, or what the logistical obstacles might be. It's also important to strengthen ties between the University and community whenever possible."

- Department Advisory Committee Member

\section{City of Eugene Pedestrian and Bicycle Strategic Plan}

The Strategic Plan articulates an overarching vision for the community and provides a concrete, specific plan of action that will empower and guide the community toward the vision.

This project involved a variety of people: approximately 500 community members provided input in the development of the strategic plan, 15 university graduate students conducted background research, facilitated meetings, and wrote the plan, 15 community members participated in the year-long Department Advisory Committee to develop the plan, 25 transportation professionals presented at the Biking and Walking Summits, and CPW estimates more than 100 participants will attend the three conference presentations. (Approximately 30 people attended CPW's presentation at the Oregon Public Works Association Conference in April; the two other presentations are scheduled for September 2008.)

The development of a rich, cross-disciplinary, experiential learning opportunity Twenty graduate students participated in the Community Planning Workshop class between January - June 2007. Not all of these students worked on the City of Eugene Pedestrian and Biking Strategic Plan; however, they benefited from the enhanced curriculum. CPW anticipates interest in the website and its curriculum as CPW is one of the most robust service learning programs in the country for community planning. This is the first time that $\mathrm{CPW}$ has made its curriculum available to the public.

\section{Case Study: Linking Experiential Education and Community Transportation Planning} This easy-to-read case study describes the University of Oregon and City of Eugene partnership and highlights the benefits of linking experiential education with transportation planning and will provide lessons learned from this project so that other communities are more equipped to develop their own partnerships.

\section{Linking Experiential Education and Community Transportation Website}


This website consolidates the products from this project and provides a wonderful resource for communities contemplating using university students to work on community transportation projects. CPW will be able to track website hits to determine interest.

\section{Conference Presentations}

April 2008, American Public Works Association: Oregon Chapter - Eugene, OR

September 2008, Oregon Planning Institute - Eugene, OR

September 2008, Pro Walk / Pro Bike - Seattle, WA 


\subsection{FURTHER ACTIVITIES}

One of the identified high priority actions in the City of Eugene Pedestrian and Bicycle Strategic Plan is to increase the number of youth walking and biking. A Safe Routes to School committee has formed to look at this issue within the community. Community Planning Workshop, in partnership with the Safe Routes to School Committee, has submitted an OTREC grant to work with youth in the local school system to better understand why some youth walk and bike to school and other do not. CPW is particularly interested in actions that the city, the school district and the community can do to encourage more youth to walk and bike to school. Results from this project will be of interest nationally as many communities are contemplating these same questions. 


\section{WORKS CITED}

${ }^{1}$ Balsas, C. "New Directions for Bicycle and Pedestrian Planning Education in the United States." Planning Practice and Research, Vol. 17, No. 1, pp. 91-105, 2002.

${ }^{2}$ Frank, L. \& Engleke, P. "Multiple Impacts of the Built Environment on Public Health: Walkable Places and the Exposure to Air Pollution." International Regional Science Review Vol. 28, Issue 2, pp. 193-216, April 2005.

${ }^{3}$ Seltzer, E.P., and Ozawa, C.P. 2002. "Clear Signals: Moving on to Planning's Promise."

Journal of Planning Education and Research, 22:77-86, Association of Collegiate Schools of Planning.

${ }^{4}$ Kotval, Z. "Experiential Learning in the Urban Planning Curriculum.” Journal of Geography in Higher Education, Vol. 27, No. 3, pp. 297-308, Nov. 2003.

${ }^{5}$ Baum, H.S. 1997. "Teaching Practice." Journal of Planning Education and Research, 17: 2129, Association of Collegiate Schools of Planning. 
P.O. Box 751

Portland, OR 97207

www.otrec.us

OTREC is dedicated to stimulating and conducting collaborative multi-disciplinary research on multi-modal surface transportation issues, educating a diverse array of current practitioners and future leaders in the transportation field, and encouraging implementation of relevant research results. 